\title{
Spatial genetic structure within three sugar maple (Acer saccharum Marsh.) stands
}

\author{
D. J. PERRY \& P. KNOWLES \\ Department of Biology and School of Forestry, Lakehead University, Thunder Bay, Ontario, Canada P7B 5E1
}

\begin{abstract}
Approximately 100 trees were sampled and mapped in each of three natural Sugar Maple (Acer saccharum Marsh.) stands in northwestern Ontario. Starch-gel electrophoresis was used to resolve five polymorphic enzyme loci from bud tissue and spatial genetic structure was examined in each of the three stands using spatial autocorrelation techniques. A significant small scale genetic structure was detected in all stands and patch widths were inferred to be approximately $20-30 \mathrm{~m}$. A nonrandom distribution of genotypes may be a reflection of restricted gene flow, selection and/or patchy establishment of genetically distinct cohorts.
\end{abstract}

Keywords: gene flow, genetic structure, Moran's $I$, spatial auto correlation.

\section{Introduction}

Most tree species are genetically diverse with the vast majority of their genetic variation residing within populations (Hamrick et al., 1981; Boyle \& Yeh, 1988). It is generally agreed that the distribution of this variation within populations is not likely to be random owing to the effects of factors such as limited seed and pollen dispersal and microhabitat selection (Levin \& Kerster, 1974; Loveless \& Hamrick, 1984; Turner et al., 1982). Knowledge of genetic structure within populations is important to forest geneticists. For example, the existence of groups of related individuals could cause inbreeding that in turn may confound the analysis of wind-pollinated provenance or progeny tests, leading to overestimation of additive genetic variance and genetic gain (Namkoong, 1966; Squillace, 1974). In addition, if an assumption of a lack of substructure is in error, biased estimates of mating system parameters may result (Ennos \& Clegg, 1982; Ritland, 1985).

Intuitively one might suspect the existence of substructuring within populations. However, the detection of a pronounced structure in natural populations of forest trees has largely eluded forest geneticists. A number of methods, most involving the use of allozymes as genetic markers, have been employed in an effort to detect and describe the genetic structure within stands. Methods have ranged from a simple visual inspection of maps depicting tree genotypes (Tigerstedt, 1973), to an examination of the correlation between complex genetic similarity measures and geo- graphic proximity (Brunel \& Rodolphe, 1985). While some investigations have revealed genetic structure (Sakai \& Miyazaki, 1972; Coles \& Fowler, 1976; Linhart et al., 1981; Cheliak et al., 1984; Knowles, 1984; Brunel \& Rodolphe, 1985), it is often weak and others have indicated nothing but a random distribution of genotypes (Tigerstedt, 1973; Guries \& Ledig, 1977; Roberds \& Conkle, 1984). Recently, spatial autocorrelation statistics (Cliff \& Ord, 1973; Sokal \& Oden, 1978a) have gained popularity among those who study genetic structure within populations of forest trees and other plant communities (Waser, 1987; Dewey \& Heywood, 1988; Epperson \& Allard, 1989; Schoen \& Latta, 1989; Knowles, 1990). Investigations of spatial autocorrelation in lodgepole pine (Pinus contorta ssp. latifolia; Epperson \& Allard, 1989) and black spruce (Picea mariana (Mill.) B.S.P.; Knowles, 1990) have indicated that in the populations studied, the distribution of single-locus genotypes is nearly random.

Genetic variation within Sugar Maple (Acer saccharum, Marsh.) is well documented. A variation has been demonstrated in growth rates among provenances (Wendel \& Gabriel, 1980), in sugar concentration among clones (Kriebel, 1989), in seed and fruit characters among and within provenances (Gabriel, 1978), and in allozyme frequencies among populations (Perry \& Knowles, 1989). Ledig \& Korbobo (1983) observed differentiation in physiological characteristics of progeny from stands separated by less than $0.8 \mathrm{~km}$. However, allozyme analysis has indicated that only about 3 per cent of the total variation at individual loci 
is among populations (Perry \& Knowles, 1989). In the present study, we focus on the approximately 97 per cent of the variation thought to reside within stands. We applied spatial autocorrelation analysis to allozyme data of three naturally occurring Sugar Maple populations with the objective of determining whether the distribution of genotypes over space is random or structured within stands.

\section{Methods}

Three mature, naturally regenerated Sugar Maple stands were selected in northwestern Ontario. Stands 1 and 2 were located near Thunder Bay while stand 3 was located near Wawa. Sugar Maple grows at moderate densities as the principal species of locally disjunct stands at both locales. Bud tissue was collected from approximately 100 contiguous trees in each stand (stand 1, $n=99$; stand 2, $n=98$; stand 3, $n=103$ ) and the positions of the sampled trees were mapped. The tissue was subjected to starch-gel electrophoresis and five polymorphic enzyme loci ( Ald-2, aldolase, E.C.4.1.2.13; Dia-3, diaphorase, E.C.1.6.4.3; $M d h-3$, malate dehydrogenase, E.C.1.1.3.7; Pgi-2, phosphoglucose isomerase, E.C.5.3.1.9; and Pgm-1, phosphoglucomutase, E.C.1.15.1.1) were resolved. Electrophoretic conditions were as previously described (Perry \& Knowles, 1989). The genetic data was coded such that single trees received allele frequency values of $0.0,0.5$ or 1.0 for each allele of every locus.

For each stand, spatial autocorrelation analysis was conducted on the coded data of individual alleles of each locus using the FORTRAN program SAAP developed by Daniel Wartenberg. Alleles with a population frequency less than 0.02 were excluded and only one allele was considered at diallelic loci as the second allele would contribute identical information. Moran's $I$ (Cliff \& Ord, 1973; Sokal \& Oden, 1978a) was estimated for each of 10 distance classes, the ranges of which were selected by equalizing sample sizes. Tests of significance $(\alpha=0.05)$, which followed equations given in Cliff \& Ord (1973), were also performed by SAAP. Values of $I$ significantly larger than the expected value of $E(I)=-(n-1)^{-1}$ indicate a greater similarity of individuals within that distance class than would be expected by chance, while values of $I$ significantly lower than $E(I)$ signify less similarity among individuals within that class than would be expected were chance the only factor determining the spatial distribution of the allele in question.

Visual examination of spatial genetic structure was facilitated through the construction of correlograms. Overall significance of individual correlograms, each constructed from a series of non-independent $I$ values, was assessed using Bonferroni's criterion (Sakai \& Oden, 1983).

\section{Results}

Spatial autocorrelation analysis yielded 8 out of 110 , 13 out of 60 , and 13 out of 130 significant Moran's $I$ statistics for stands 1, 2 and 3, respectively (Table 1). Several observations were noteworthy. Seven of 30 test statistics for the shortest distance (class 1) were significant with the proportions per stand being $0.18,0.50$ and 0.15 for the three stands respectively. All of these significant $I$ values were greater than $E(I)$, indicating that individuals possessing similar alleles were proximal more often than expected by chance alone. Throughout the midrange, mean $I$ values tended to decrease in successive distance classes, which suggests that in this range pairs of individuals were generally less akin with increasing inter-tree distances. In the highest distance classes many of the significant $I$ values were positive. The patterns associated with either positive or negative $I$ values in these distance classes are difficult to ascertain. While negative autocorrelation is expected in higher distance classes where individuals occur on a gradient or cline (Sokal \& Oden, $1978 b$ ), positive autocorrelation may result if the gradient is circular or symmetrical (Sokal \& Oden, 1978 b) or if patch distribution is 'regular' (Epperson \& Clegg, 1986). The signs at high distance classes could also be influenced by certain patches occurring near the borders of the sampled area (Epperson \& Clegg, 1986).

According to Sokal (1979), the distance at which a correlogram first intercepts the abscissa in this case $E(I)]$ represents the shortest side of an irregularly

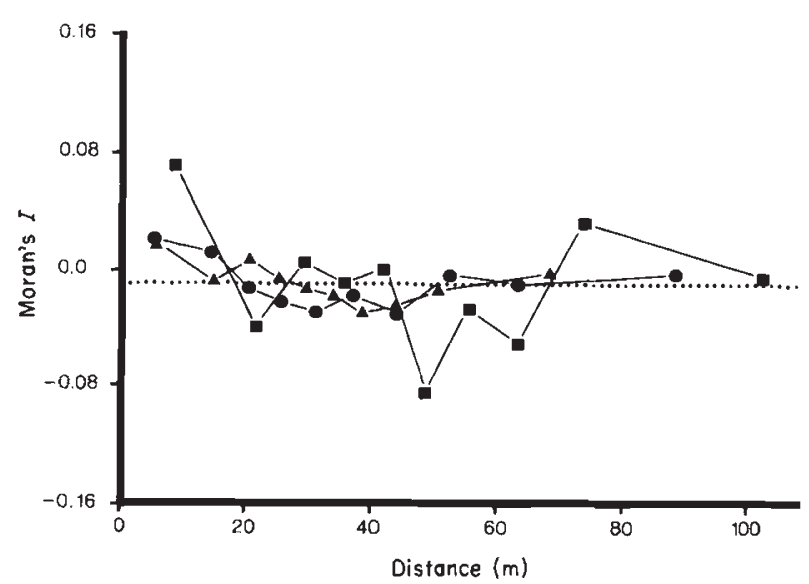

Fig. 1 Mean correlograms for each of three sugar maple stands: stand $1(\bullet)$, Stand $2(\bullet)$ and Stand $3(\Delta)$. The dotted line at -0.01 is $E(I)$, the expected value of Moran's $I$. 


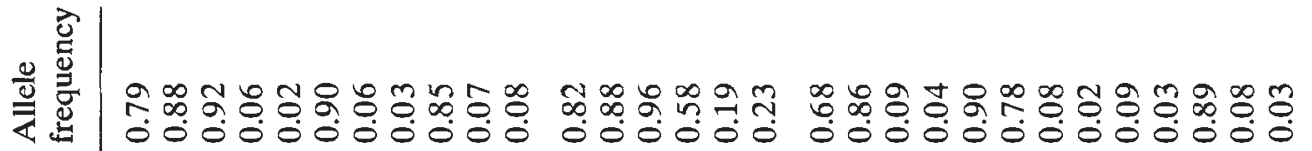
40

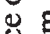

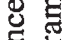

ฮू

柁

战

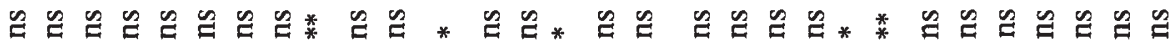

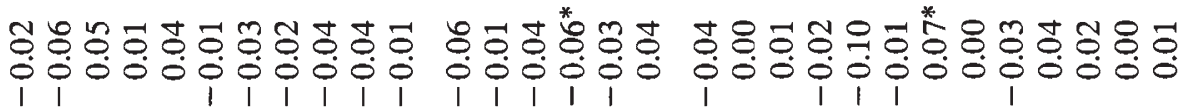

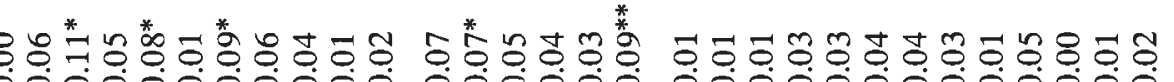

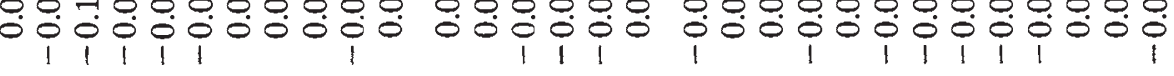

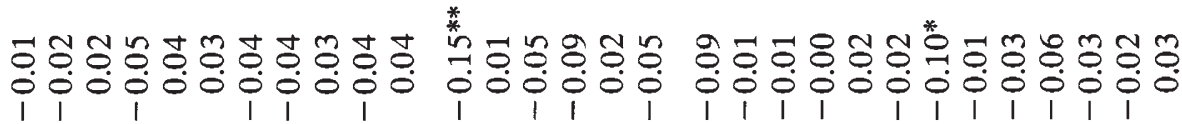

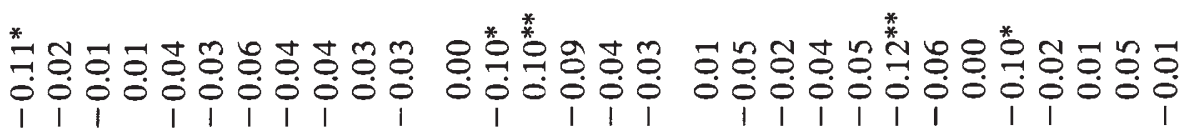

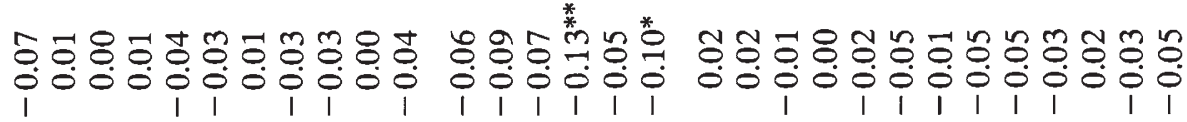

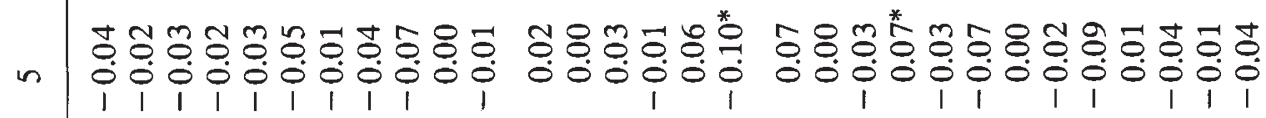

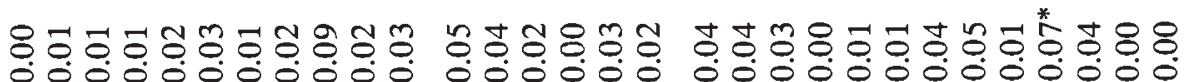

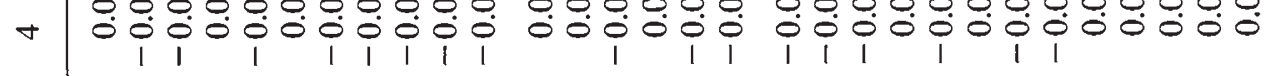

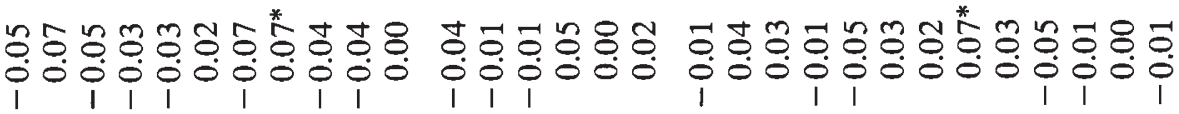

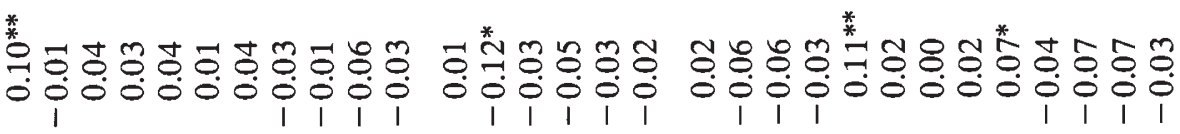
1 l 1 $1 \quad 11$

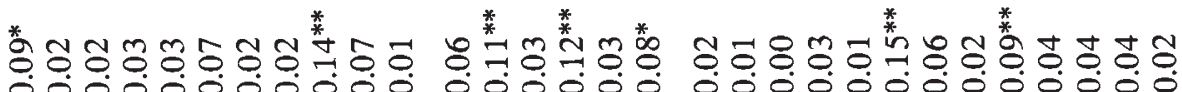
$-$ $0 \dot{0} 0 \dot{0} 0 \dot{0} 0 \dot{1} 0 \dot{0}$

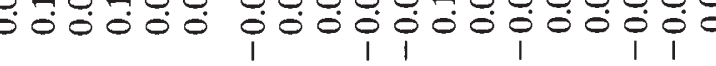

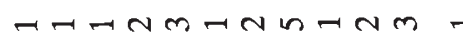

: $\frac{1}{2}$ $\frac{1}{8}$

\begin{tabular}{|c|c|c|c|}
\hline$\rightarrow \rightarrow \sim m$ & -7 & -7 & \\
\hline 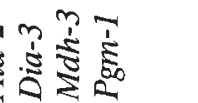 & 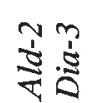 & $\frac{m}{5} \tilde{\Sigma}$ & 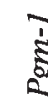 \\
\hline
\end{tabular}

0

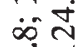

จำ

n

in 0

aำ

in்

iิ

$1+\infty$

字它向

$\infty a^{n}$

$\dot{\infty} \ddot{\infty} \dot{0}$

守列

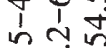

क्षि

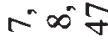

जितें

車的官

I 12

过

ดัก์ษ

in $\ddot{-1} \infty$

में تَّ

का m

艧

nิ

$\dot{\infty} \dot{m} r$

$\infty \dot{\sim}$

Tे

लें

ชn

तेंo

ஸेळ

11 1

$\infty$ i

$m^{m}-\tilde{N}$

نे

$\infty$ i

1 $1 \hat{1}$

$=$ in

तm

ờ

चึ

ㄴ. I

$0=0$

$=$ त

ष्त

踣

ळै

5

- E E

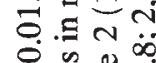

$\dot{0}$
$\mathrm{w}$

* ปั

ตํํㅇ용

원이

$v$.

* 
shaped patch. The mean correlograms of each of the three stands (Fig. 1) indicate that patch sizes were approximately $20-30 \mathrm{~m}$ across.

\section{Discussion}

Comparisons among spatial autocorrelation studies are not easily made as there is no test available for the difference between correlograms (Sokal \& Wartenberg, 1983) and factors such as sample sizes, and allele frequencies may affect one's ability to detect an existing genetic structure. However, one observation suggests that the amount of structure within these maple stands may be greater than that of two Black Spruce populations studied via similar methods (Knowles, 1990). Although the sample sizes (numbers of trees per population) of the present study are notably smaller than those of the Knowles (1990) study, the proportions of significant $I$ values observed in the smallest distance class of each population were greater in the present study. While Knowles described the genetic structure within Black Spruce stands as 'subtle', we suggest that the degree of structuring within the present Sugar Maple stands may be better described as moderate.

Factors that may contribute to genetic structure include restricted pollen and seed dispersal, and spatially varying selection. Little information is available concerning seed dispersal in natural Sugar Maple stands. In open conditions, an order of magnitude decrease in seedling density was reached over a distance of $31 \mathrm{~m}$ from a seed source (Johnson, 1988). The potential dispersal distance of Sugar Maple samaras is great, perhaps hundreds of metres, but in dense stands where samaras may strike other trees and shrubs in the course of flight, dispersal may be limited (Guries \& Nordheim, 1984). Information pertaining to pollen flow is even less complete. One might predict pollen dispersal in Sugar Maple to be relatively low because it is at least partially entomophilous and insects may tend to visit proximal trees, but it has been shown that wind alone can provide sufficient pollen for pollination (Gabriel \& Garrett, 1984). Selection has been suggested by some researchers as a possible causal mechanism contributing to observed spatial structure (Linhart et al., 1981; Epperson \& Allard, 1989) and evidence that may refute the selective neutrality of some allozyme loci has been presented (Johnson, 1972; Nevo et al., 1986).

Perhaps a patchy genetic structure within stands is a product of the dynamics of Sugar Maple regeneration. In the extreme case, vegetative reproduction would result in clusters of genetically identical individuals. Sugar Maple is capable of producing clones (Fayle, 1964) but, based on field observations and examina- tion of multilocus genotypes, we judged the sampled trees to be of seed origin. While studying 'gap phase replacement' in a maple-basswood forest, Bray (1956) found that areas where the canopy was opened by disturbance were quickly covered by Sugar Maple seedlings. Willis \& Coffman (1975) noted even-aged groups of saplings where disturbances had occurred. They suggest that there may be a 'spatial contagious pattern' with respect to age in Sugar Maple, with stands being composed of even-aged groups and that within a stand such groups may mature, die, and be replaced by new regeneration in a relatively short period of time. Of course, such a process could only account for the observed spatial genetic patterns if genetic differences exist among the even-aged groups (or cohorts). Mulcahy (1975) presents evidence of such differentiation. We did not determine ages of sampled trees and this is clearly an area in need of further study.

Variation in size and distinctness of patches among sampled areas of the three stands could be due to a number of factors. With isolation-by-distance (limited dispersal) the size of homogenous areas increases with larger neighbourhood sizes but as the areas increase in size, contrast is lost (Sokal \& Wartenberg, 1983). Under selection, patches of genetic similarity would be expected to correspond to environmental patch structure. If the presence of cohorts was a source of genetic architecture, patches of genetically similar individuals would be affected in size by the magnitude of founding disturbances and in distinctness by the degree of genetic differentiation among cohorts.

If demographic patterns contribute to the formation of a spatial genetic structure within Sugar Maple stands as we propose, then the potential for the development of a spatial genetic structure may be greater in species that exist in uneven-aged stands than in species such as Black Spruce or Lodgepole Pine, whose populations are more typically even-aged. The validity of this hypothesis can only be determined through continued research. To this end, joint examination of genetic structure and age distribution within populations is likely to prove most efficacious.

\section{Acknowledgements}

This research was supported by the Natural Sciences and Engineering Research Council of Canada (grant A7652 to P.K.). We thank Gail Jackson, Colin Templeton, Karen Spinney-Helmer and Lea Tarnowsky for assisting in the field and laboratory and D. Wartenberg for providing computer programs. 


\section{References}

BOYLE, T. J. B. AND YEH, F. C. 1988. Within-population genetic variation - implications for selection and breeding. In: Morgenstern, E. K. and Boyle, T. J. B. (eds), Proceedings of the Twenty-First Meeting of the Canadian Tree Improvement Association. Part 2, Can. For. Serv., Petawawa Nat. For. Inst., Chalk River, Ontario, pp. 20-42.

BRAY, R. J. 1956. Gap phase replacement in a maple-basswood forest. Ecology, 37, 598-600.

BRUNEL, D. AND RODOLPHE, F. 1985. Genetic neighbourhood structure in a population of Picea abies L. Theor. Appl. Genet., 71, 101-110.

CheliaK, W. M., PITEL, J. A. AND MURray, G. 1984. Population structure and the mating system of white spruce. Can. J. For. Res., 15, 301-308.

COLES, J. F. AND FOWLER, D. P. 1976. Inbreeding in neighboring trees in two white spruce populations. Silvae Genet., 25, 29-34.

ClifF, A. D. AND ORD, J. K. 1973. Spatial Autocorrelation. Pion Ltd, London.

DEWEY, S. E. AND HEYWOOD, J. S. 1988. Spatial genetic sructure in a population of Psychotria nervosa. I. Distribution of genotypes. Evolution, 42, 834-838.

ENNOS, R. A. AND CLEGG, M. T. 1982. Effect of population substructuring on estimates of outcrossing rate in plant populations. Heredity, 48, 283-292.

EPPERSON, B. K. AND ALLARD, R. W. 1989. Spatial autocorrelation analysis of the distribution of genotypes within populations of lodgepole pine. Genetics, 121, 369-377.

EPPERSON, B. K. AND CLEGG, M. T. 1986. Spatial-autocorrelation analysis of flower color polymorphisms within substructured populations of morning glory (Ipomoea purpurea). Am. Nat., 128, 840-858.

FAYLE, D. C. F. 1964. Layering habit of sugar maple. For. Chron., 40, 116-121.

GABRIEL, w. J. 1978. Genetic variation in seed and fruit characters in sugar maple. USDA For. Serv. Res. Pap. NE404.

GABRIEL, W. J. AND GARRETT, P. w. 1984. Pollen vectors in sugar maple (Acer saccharum). Can. J. Bot., 62, 2889-2890.

GURIES, R. P. AND LEDIG, F. T. 1977. Analysis of population structure from allozyme frequencies. In: Proceedings of the 4th Southern Forest Tree Improvement Conference, Gainesville, FL, pp. 246-253.

GURIES, R. P. AND NORDHEIM, E. v. 1984. Flight characteristics and dispersal potential of maple samaras. For. Sci., $\mathbf{3 0}$, 434-440.

HAMRICK, J. L., MTTTON, J. B. AND LINHART, Y. B. 1981. Levels of genetic variation in trees: Influence of life history characteristics. In: Conkle, M. T. (ed) Isozymes of North American Forest Trees and Forest Insects. USDA For. Serv. Gen. Tech. Rep. PSW-48, USDA Forest Service, Berkeley, CA, pp. 35-41.

JOHNSON, C. w. 1988. Estimating dispersibility of Acer, Fraxinus and Tilia in fragmented land scapes from patterns of seedling establishment. Landscape Ecol., 1, 175-187.

JOHNSON, G. B. 1972. Evidence that enzyme polymorphisms are not selectively neutral. Nat. New Biol., 237, 170-171.
KNOWLES, P. 1984. Genetic variability among and within closely spaced populations of lodgepole pine. Can. J. Genet. Cytol., 26, 177-184.

KNOWLES, P. 1990. Spatial genetic structure within two natural stands of black spruce [Picea mariana (Mill.) B.S.P.]. Silvae Genet., in press.

KRIEBEL, H. B. 1989. Genetic improvement of sugar maple for high sap sugar content. I. Clone selection and seed orchard development. Can. J. For. Res., 19, 917-923.

LEDIG, F. T. AND KORBOBO, D. R. 1983. Adaptation of sugar maple populations along altitudinal gradients: photosynthesis, respiration, and specific leaf weight. Am. J. Bot., 70, 256-265.

LEVIN, D. A. AND KERSTER, H. W. 1974. Gene flow in seed plants. Evol. Biol., 7, 139-220.

LINHART, Y. B., MITTON, J. B., STURGEON, K. B. AND DAVIS, M. L. 1981. Genetic variation in space and time in a population of ponderosa pine. Heredity, 46, 407-426.

LOVELESS, M. D. AND HAMRICK, J. L. 1984. Ecological determinants of genetic structure in plant populations. Ann. Rev. Ecol., 15, 65-95.

MULCAHY, D. L. 1975. Differential mortality among cohorts in a population of Acer saccharum (Aceraceae) seedlings. Am. J. Bot., 62, 422-426.

NAMKOONG, G. 1966. Inbreeding effects on estimation of genetic additive variance. For. Sci., 12, 8-13.

NEVo, E., BeILES, A., KAPLAN, D., GOLENBERG, E. E., OLSVIGWHITTAKER, L. AND NAVEH, Z. 1986. Natural selection of allozyme polymorphisms: a microsite test revealing ecological genetic differentiation in wild barley. Evolution, 40, 13-20.

PERRY, D. J. AND KNOWLES, P. 1989. Allozyme variation in sugar maple at the northern limit of its range in Ontario, Canada. Can. J. For. Res., 19, 509-514.

RITLAND, K. 1985. The genetic-mating structure of subdivided populations. I. Open-mating model. Theor. Popul. Biol., 27, 51-74.

ROBERDS, J. H. AND CONKLE, M. T. 1984. Genetic structure in loblolly pine stands: allozyme variation in parents and progeny. For. Sci., 30, 319-329.

SAKAI, A. K. AND ODEN, N. L. 1983. Spatial pattern of sex expression in silver maple (Acer saccharinum L.): Morista's index and spatial autocorrelation. Am. Nat., 122, 489-508.

SAKAI, K.-I. AND MIYAZAKI, Y. 1972. Genetic studies in natural populations of forest trees. Silvae Genet., 21, 149-154.

SCHOEN, D. F. AND LATTA, R. G. 1989. Spatial autocorrelation of genotypes in populations of Impatiens pallida and Impatiens capensis. Heredity, 63, 181-189.

SOKAL, R. R. 1979. Ecological parameters inferred from spatial correlograms. In: Patil, G. P. and Rosenzweig, M. L. (eds) Contemporary Quantitative Ecology and Related Ecometrics, International Cooperative Publishing House, Fairland, MD, pp. 167-196.

SOKAL, R. R. AND ODEN, N. L. 1978a. Spatial autocorrelation in biology. 1. Methodology. Biol. J. Linn. Soc., 10, 199-228.

SOKAL, R. R. AND ODEN, N. L. 1978b. Spatial autocorrelation in biology. 2. Some biological implications and four applications of evolutionary and ecological interest. Biol. J. Linn. 
Soc., 10, 229-249.

SOKAL, R. R. AND WARTENBERG, D. E. 1983. A test of spatial autocorrelation analysis using an isolation-by-distance model. Genetics, 105, 219-237.

SQUILLACE, A. E. 1974. Average genetic correlations among offspring from open-pollinated forest trees. Silvae Genet., 23, 149-156.

TIGERSTEDT, P. M. A. 1973. Studies on isozyme variation in marginal and central populations of Picea abies L. Hereditas, $75,47-60$.

TURNER, M. E., STEPHENS, J. C. AND ANDERSON, W. W. 1982. Homozygosity and patch structure in plant populations as a result of nearest-neighbour pollination. Proc. Natl Acad.
Sci., USA, 79, 203-207.

WASER, N. M. 1987. Spatial genetic heterogeneity in a population of the montane perennial plant Delphinium nelsonit. Heredity, 58, 249-256.

WENDEL, G. W. AND GABRIEL, w. J. 1980. Sugar maple provenance study: West Virginia outplanting -10 -year results. USDA For. Serv. Res. Paper NE-460.

WILLIS, G. L. AND COFFMAN, M. S. 1975. Composition, structure, and dynamics of climax stands of eastern hemlock and sugar maple in the Huron Mountains, Michigan. Tech. Bull. No. 13., Dept. of Forestry, Michigan Technological University, Houghton Michigan. 